\title{
Study of Ruthenium Complex Sensitizer and Gold Nanoparticles Doped Flexible Organic Solar Cells
}

\author{
Cheng-Chiang Chen and Lung-Chien Chen \\ Department of Electro-Optical Engineering, National Taipei University of Technology, No. 1, Section 3, Chung-Hsiao East Road, \\ Taipei 106, Taiwan \\ Correspondence should be addressed to Lung-Chien Chen, ocean@ntut.edu.tw
}

Received 12 June 2012; Accepted 3 September 2012

Academic Editor: Fengqiang Sun

Copyright ( $\odot 2012$ C.-C. Chen and L.-C. Chen. This is an open access article distributed under the Creative Commons Attribution License, which permits unrestricted use, distribution, and reproduction in any medium, provided the original work is properly cited.

This work presents a flexible organic solar cell with a structure for ITO/PEDOT:PSS/P3HT:PCBM + ruthenium complex sensitizer and Au nanoparticles on a flexible substrate. The process and thickness of the PEDOT:PSS hole transport layer and P3HT:PCBM active layer were optimized. A ruthenium complex sensitizer and Au nanoparticles were then introduced into the P3HT:PCBM active layer to improve the performance of solar cells. For the ITO/PEDOT:PSS/P3HT:PCBM + ruthenium complex sensitizer and $\mathrm{Au}$ nanoparticles structure on a flexible polyimide (PI) substrate under 0.1 and 1 sun conditions, the measured short-circuit current density $\left(J_{\text {sc }}\right)$, open-circuit voltage $\left(V_{\mathrm{oc}}\right)$, fill factor $(\mathrm{FF})$, and efficiency $(\eta)$ are 3.89 and $9.67 \mathrm{~mA} / \mathrm{cm}^{2}, 0.45$ and $0.45 \mathrm{~V}, 0.266$ and 0.232 , and 4.65 and $1.01 \%$, respectively.

\section{Introduction}

Flexible organic solar cells (FOSCs) have received considerable attention recently owing to their ability to be fabricated at low temperatures, economic cost, large area production, high flexibility, roll-to-roll manufacturing, and easy fabrication, such as by spin coating, [1-5] printing, [6-9] slot-die coating, [9-12] or evaporation [13, 14]. The organic active layer in FOSCs typically consists of a p-conjugated polymer donor and acceptor. The power conversion efficiency of (PCE) of FOSCs has been improved to 2.5\% 3.7\% using a bulk heterojunction $(\mathrm{BHJ})$ structure comprising a blended film of poly(3-hexylthiophene) (P3HT) as the donor and $[6,6]$-phenyl- $\mathrm{C}_{61}$-butyric acid methyl ester (PCBM) as the acceptor. Their PCE is significantly lower much than that of organic-based PTB7/ $\mathrm{PC}_{71} \mathrm{BM}$ structure solar cells on a glass substrate, that is, $7.4 \%[1,11,15-18]$. However, polyimide (PI) substrates have become conventionally used in flexible electronic devices owing to their high transition temperatures, low surface roughness, low coefficients of thermal expansion, and high chemical resistance under typical fabrication conditions $[1,19,20]$.
Owing to the inherent symmetry of the BHJ active layer, the nature of the electrodes largely determines the anode and cathode of the device [21]. Therefore, this work attempts to improve the PCE of solar cells by introducing a cis-bis(thiocyanato) bis $\left(2,2^{\prime}\right.$-bipyridyl-4,4' -dicarboxylate) ruthenium bis(tetrabutylammonium) (N719) sensitizer (Everlight Chemical Industrial Co., Taiwan) and Au nanoparticles (GNPs) (100 ppm, particle size: $2-5 \mathrm{~nm}, \mathrm{SD}$ Technology Co., Taiwan) into the active layer of the FOSCs. The N719 and GNPs can achieve electron/hole collection efficiently. The characteristics of the ITO/PEDOT:PSS/ P3HT:PCBM+N719+GNPs structure are also studied.

\section{Experiment Details}

Figure 1(a) shows the structure of flexible solar cells using $\mathrm{P} 3 \mathrm{HT}$ as the electron donor and PCBM as the electron acceptor fabricated on semitransparent ITO-coated polyethylene terephthalate $(\mathrm{PET})$ substrate (sheet resistance $=15 \Omega / \square$ and thickness $=178 \mu \mathrm{m})($ CPFilms Inc., Taiwan $)$ and PI substrate (sheet resistance $=15 \Omega / \square$ and thickness $=130 \mu \mathrm{m})(\mathrm{CPFilms}$ Inc., Taiwan), respectively. The transmittance of both PET 

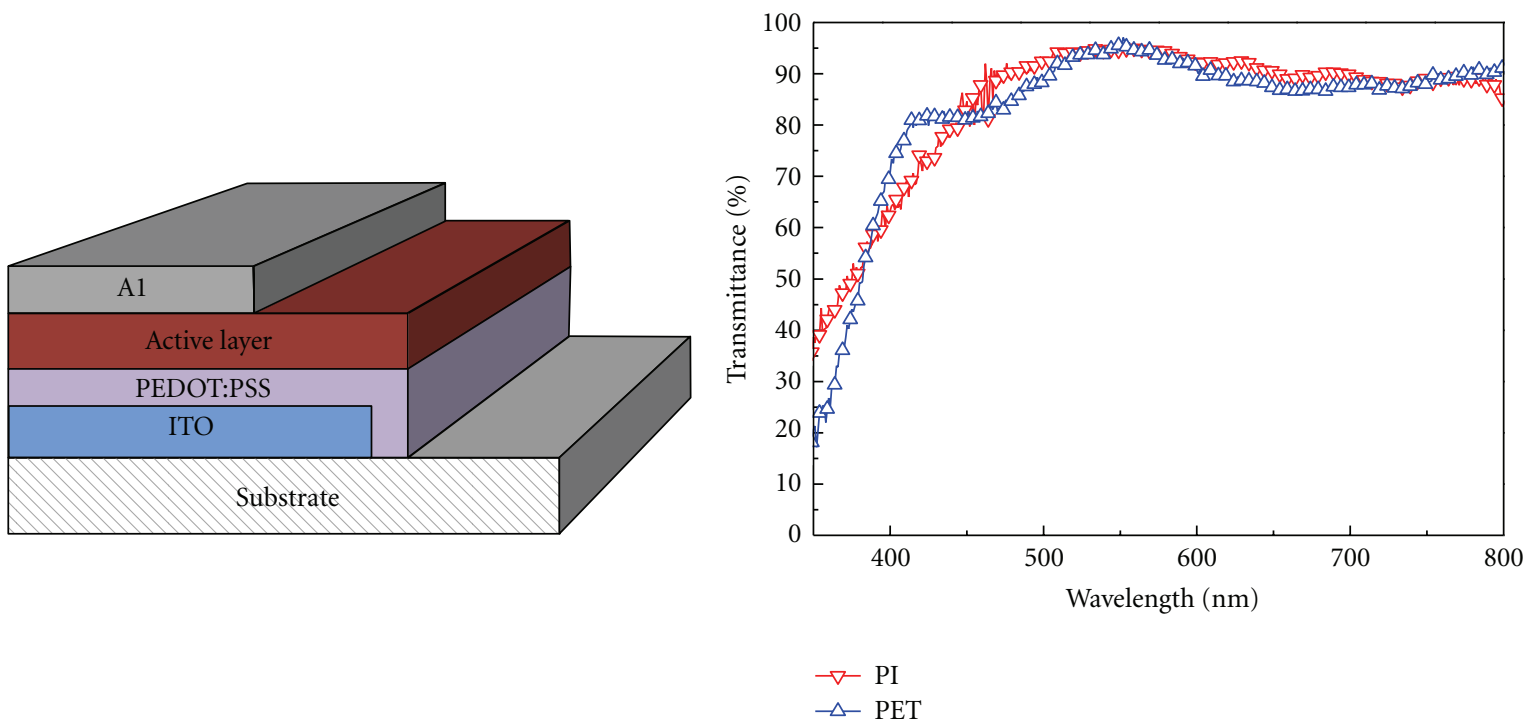

(a)

(b)

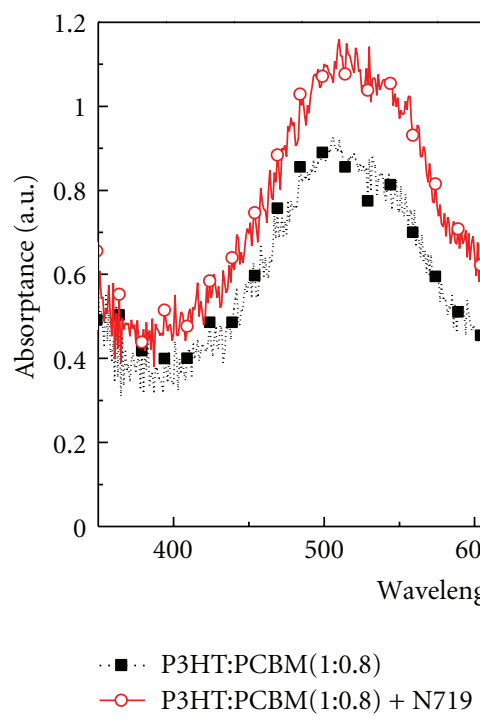

(c)

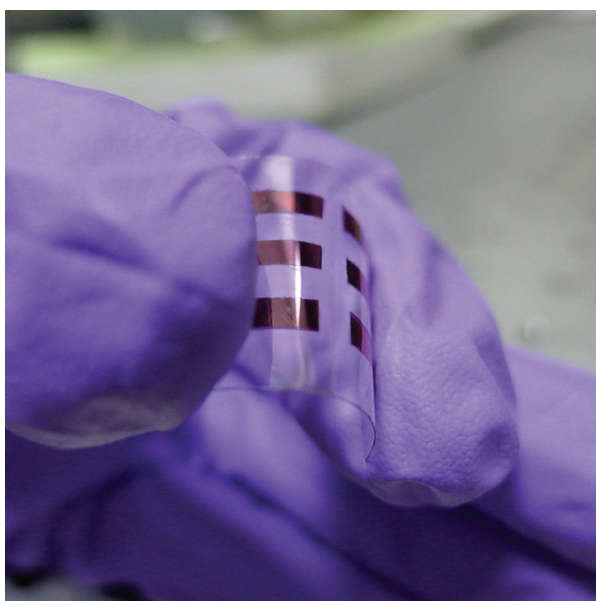

(d)

FIgure 1: (a) Structure of a flexible organic solar cell. (b) Transmittance of PET and PI substrates with ITO layer. (c) Absorbance of P3HT:PCBM and P3HT:PCBM+N719. (d) Optical image of a flexible organic solar cell.

and PI substrates with ITO layer was about $95 \%$ at $550 \mathrm{~nm}$, as shown in Figure 1(b). Therefore, PET and PI substrates are suitable for FOSCs. PEDOT:PSS hole transport layer was spun on the substrate with ITO layer and annealed at various temperatures for $10 \mathrm{~min}$ in a vacuum. An attempt was made to achieve the required viscosity in the range of 2 to $30 \mathrm{cps}$ and reduce the tension of the PEDOT:PSS layer by adding a surfactant Triton X-100 to the PEDOT:PSS solution [22]. Next, the PEDOT:PSS solution was filtered through $0.45 \mu \mathrm{m}$ PP syringe filters before spin coating on the substrate. Additionally, P3HT and PCBM were blended with 1,2-dichlorobenzene(DCB) $(1: 0.8$ at wt $\%)$ as an active layer. The solution was then filtered through $0.45 \mu \mathrm{m}$ PP syringe filters before spin coating. P3HT:PCBM blended solution was spin coated on a dried PEDOT:PSS thin film and annealed at $140^{\circ} \mathrm{C}$ for $10 \mathrm{~min}$ in a vacuum. Finally, $\mathrm{Al}$ layer was deposited under a base pressure of $1 \times 10^{-6} \mathrm{Torr}$. $\mathrm{Al}$ cathode was deposited through a shadow mask to a thickness of $70 \mathrm{~nm}$, given an active area of $2 \mathrm{~mm} \times 5 \mathrm{~mm}$. Therefore, the cell has an active area of $2 \mathrm{~mm} \times 5 \mathrm{~mm}$. Distance from the crucible to the substrate was fixed at $20 \mathrm{~cm}$, and a substrate holder was rotated continuously to ensure uniform films. Next, film thickness and deposition rate, which was adjusted by SEM, were monitored using quartz crystal microbalance (QCM). Figure 1(c) shows the absorbance of P3HT:PCBM and P3HT:PCBM+N719. Therefore, in this study, the N719 


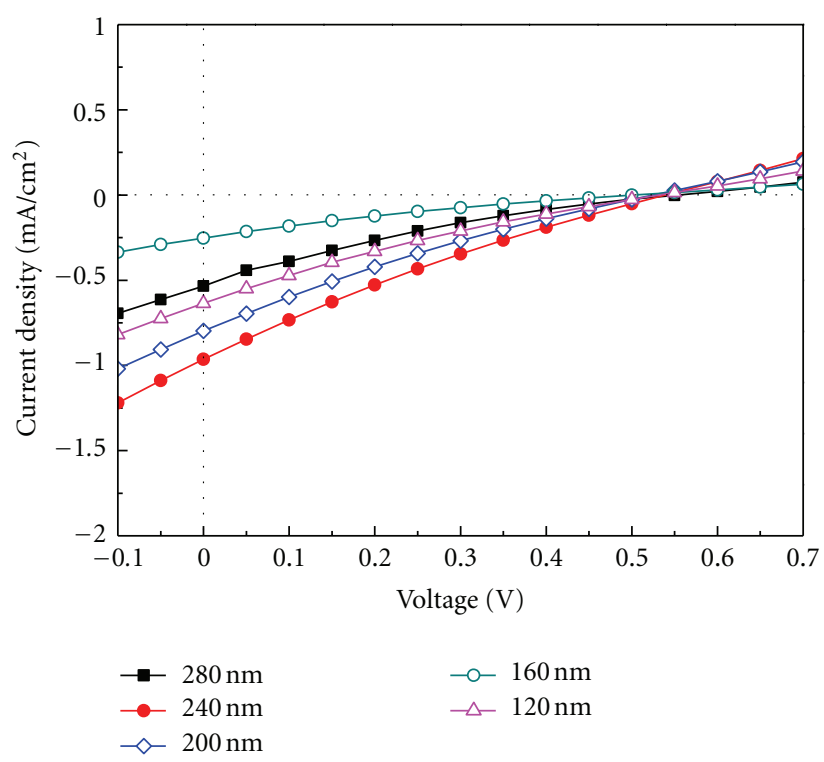

(a)

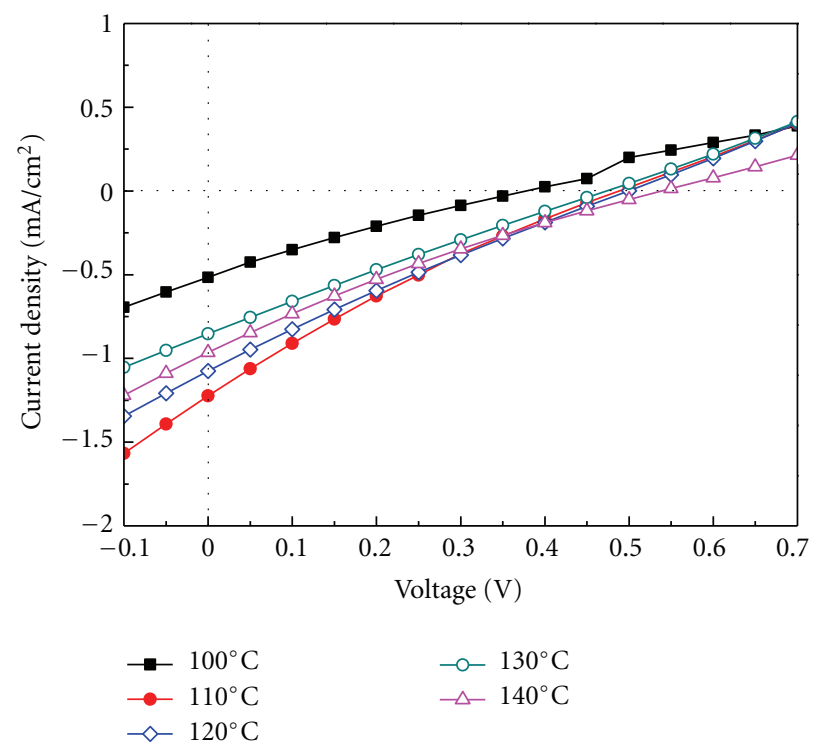

(b)

FIgURE 2: The $J-V$ characteristics of the solar cells with PEDOT:PSS hole transport layer in (a) various thicknesses and (b) various annealing temperatures.

ruthenium complex sensitizer is employed to improve the absorption of light and the performance of cell. Figure 1(d) shows the flexibility of the as-prepared cell.

The current density-voltage $(J-V)$ characteristics were then measured using a Keithley 2420 programmable sourcemeter under irradiation by a solar simulator with a $250 \mathrm{~W}$ xenon lamp. Finally, the irradiation power density in the surface of the sample was calibrated as 100 and $1000 \mathrm{~W} / \mathrm{m}^{2}$ incident power densities.

\section{Results and Discussion}

This work attempted first to optimize the hole transport layer PEDOT:PSS based on the structure of Figure 1(a) by using a $100 \mathrm{~nm}$-thick P3HT:PCBM active layer annealed at $140^{\circ} \mathrm{C}$. Figures 2(a) and 2(b) plot the $J-V$ characteristics of the ITO/PEDOT:PSS/P3HT:PCBM/Al solar cells with various hole transport layer thicknesses and annealing temperatures under illumination, respectively. According to Figure 2(a), increasing the thickness of the PEDOT:PSS layer decreased both the transparency and sheet resistance, subsequently affecting the photocurrent and fill factor of the solar cells. However, decreasing the transparency of the PEDOT:PSS layer reduced the available photons to be absorbed by the active layer ultimately leading to a lower photocurrent density. However, this lowering of the photocurrent was offset by an increase in the fill factor due to the low sheet resistance [23]. The photocurrent of cells increased with an increasing annealing temperature, as shown in Figure 2(b). The photocurrent density increases from $0.516 \mathrm{~mA} / \mathrm{cm}^{2}$ $\left(100^{\circ} \mathrm{C}\right.$ annealing) to $1.24 \mathrm{~mA} / \mathrm{cm}^{2}\left(110^{\circ} \mathrm{C}\right.$ annealing $)$ and then decreases to $1.08 \mathrm{~mA} / \mathrm{cm}^{2}\left(120^{\circ} \mathrm{C}\right.$ annealing), which subsequently increases to $0.97 \mathrm{~mA} / \mathrm{cm}^{2}\left(140^{\circ} \mathrm{C}\right.$ annealing $)$, as shown in Figure 2(b). The photocurrent of cells increased with an increasing annealing temperature as the annealing temperature increases from 100 to $110^{\circ} \mathrm{C}$. This indicates a variation in the conduction mechanism from the nearest neighbor hopping at the beginning of the heat treatment to the charging-energy limited tunneling between the conductive grains due to the shrinking of the PEDOT conductive grains [24]. The photocurrent of cells decreased with an increasing annealing temperature as the annealing temperature increases from 110 to $130^{\circ} \mathrm{C}$. This may attributed to the oxidation or degradation of the PEDOT. Then, the photocurrent of cells increased with an increasing annealing temperature as the annealing temperature increases from 130 to $140^{\circ} \mathrm{C}$ owing to the PSS segregation effects [25]. The optimum thickness and annealing temperature of the PEDOT:PSS layer is $240 \mathrm{~nm}$ and $110^{\circ} \mathrm{C}$, respectively.

Figure 3 plots the $J-V$ characteristics of the ITO/PEDOT: PSS/P3HT:PCBM/Al solar cells with the optimized hole transport layer and various thicknesses of the active layer under illumination. Table 1 lists the characteristic parameters of solar cells on various substrates. The parameters of a solar cell with P3HT:PCBM active layer on the PI substrate exhibited $J_{\mathrm{sc}}=3.18 \mathrm{~mA} / \mathrm{cm}^{2}, V_{\mathrm{oc}}=0.4 \mathrm{~V}, \mathrm{FF}=$ 0.257 , and a PCE of $3.27 \%$, respectively. According to this table, the photocurrent of cells increases since the number of photogenerated electron-hole pairs increases with an increasing thickness of the active layer. However, the photocurrent decreases as the thickness of the active layer is higher than $200 \mathrm{~nm}$. The thickness of the active layer increases, subsequently degrading the $J-V$ characteristics and the fill factor. The solar cell can be modeled as an equivalent circuit consisting of a current generator of $J_{\mathrm{sc}}$ and two resistances, series resistance $\left(R_{s}\right)$ and shunt resistance $\left(R_{\mathrm{sh}}\right)$. If the $R_{\mathrm{sh}}$ is sufficiently large to be neglected, the effect of the 
TABLE 1: The parameters of solar cells with P3HT:PCBM active layer.

\begin{tabular}{lcccc}
\hline Substrate & $V_{\mathrm{oc}}(\mathrm{V})$ & $J_{\mathrm{sc}}\left(\mathrm{mA} / \mathrm{cm}^{2}\right)$ & $\mathrm{FF}$ & \\
\hline Glass & 0.45 & 3.61 & 0.253 & 4.1 \\
PI & 0.4 & 3.18 & 0.257 & 3.27 \\
PET & 0.4 & 2.14 & 0.261 & 2.24 \\
\hline
\end{tabular}

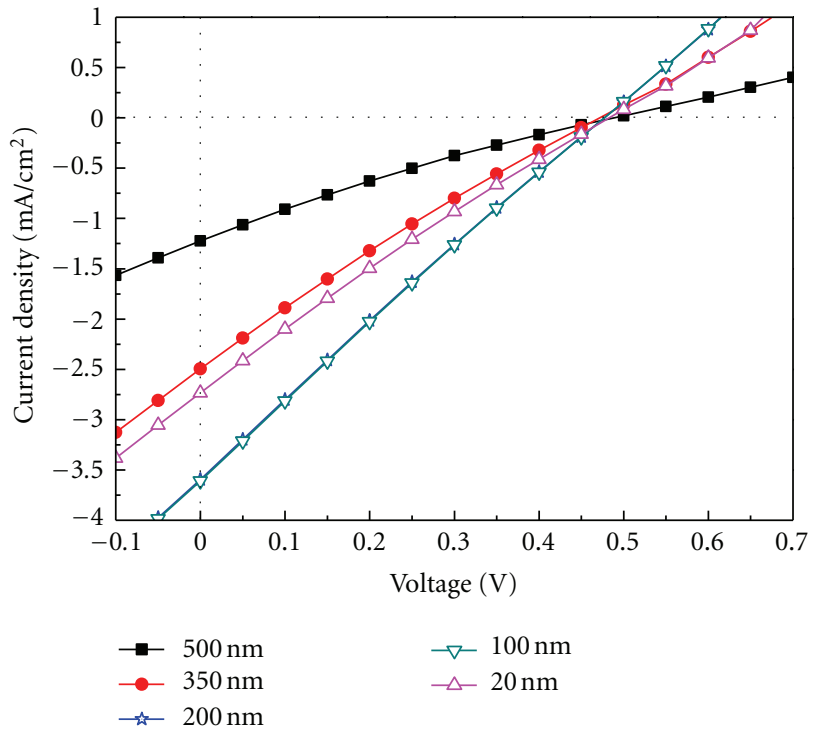

(a)

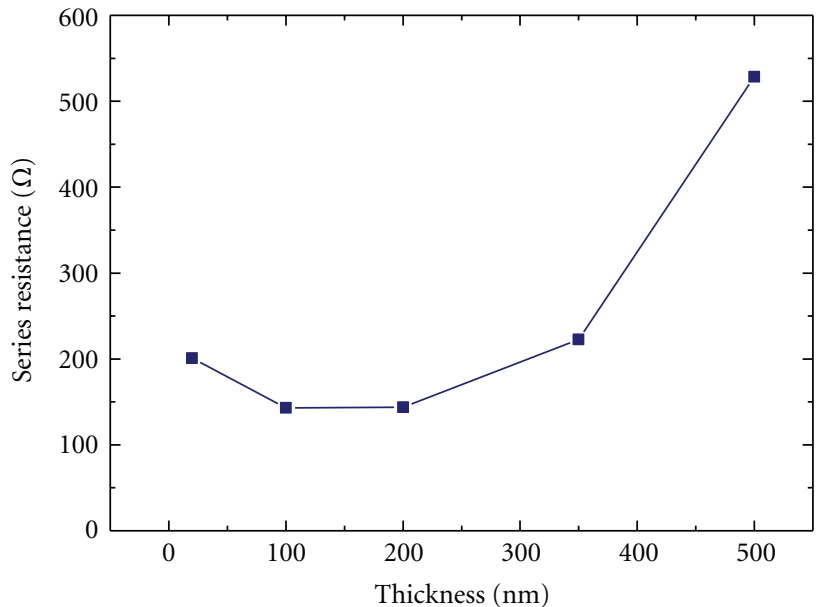

(b)

Figure 3: (a) The $J-V$ characteristics of the solar cells with various thicknesses of P3HT:PCBM active layer on the PI substrates. (b) The series resistance of cells with various thickness active layers.

$R_{s}$ on the $I-V$ characteristics can be taken into account as shown below $[26,27]$ :

$$
I=I_{s}\left[\exp \left(\frac{q\left(V-I R_{s}\right)}{n k T}\right)-1\right]-I_{\mathrm{ph}},
$$

where $I_{\mathrm{ph}}$ is the photocurrent, $I_{s}$ is the saturation current, and $n, k$, and $T$ are the ideality factor, Boltzmann constant, and temperature, respectively. Simple mathematical manipulation of (1) obtains [27]

$$
\frac{d V}{d I}=R_{s}+\frac{n k T}{q}\left(I+I_{p h}\right)^{-1} .
$$

As shown in Figure 3(b), the cell with $100 \mathrm{~nm}$-thick active layer have a smaller series resistance $(\sim 140 \Omega)$, and the cell with $500 \mathrm{~nm}$-thick active layer have a larger series resistance $(\sim 528 \Omega)$. A thicker P3HT:PCBM active layer implies a higher series resistance and poorer transparency, subsequently increasing of $R_{s}$ and lowering of photocurrent, and degrading its performance $[23,28]$. Therefore, the effective absorption of P3HT:PCBM active layer can be optimized by varying the active layer thickness.

Previous studies have applied a traditional ruthenium complex sensitizer cis-bis(thiocyanato) bis(2,2' -bipyridyl$4,4^{\prime}$-dicarboxylate) ruthenium bis(tetrabutylammonium) (N719) in dye-sensitized solar cells to extend the optical threshold wavelength since the N719 sensitizer should absorb photons from the visible to near-infrared (NIR) region of the solar spectrum while maintaining sufficient thermodynamic driving force for the electron injection and dye regeneration process [29-32]. This work also attempted to increase the efficiency of flexible solar cells by introducing N719 into the P3HT:PCBM active layer. Figure 4 plots the $J-V$ characteristics of the ITO/PEDOT:PSS/P3HT:PCBM+N719/Al (N719 $=0.3 \mathrm{mg}$ ) solar cells under illumination. Table 2 lists the characteristic parameters of solar cells with various structures. The parameters of solar cell with P3HT:PCBM+N719 active layer on the PI substrate exhibited $J_{\mathrm{sc}}=3.89 \mathrm{~mA} / \mathrm{cm}^{2}$, $V_{\mathrm{oc}}=0.4 \mathrm{~V}, \mathrm{FF}=0.258$, and a PCE of $3.68 \%$, respectively. Notably, the PCE was improved by approximately $12.5 \%$ over that of the control sample. This improvement in PCE can be attributed to that the absorption of P3HT:PCBM active with N719 sensitizer have better than that of P3HT:PCBM active layer in visible, especially in the wavelength of 500-600 nm, as shown in Figure 1(c).

Figure 5 plots the $J-V$ characteristics of the ITO/PEDOT: PSS/P3HT:PCBM+N719+GNPs/Al (P3HT:PCBM = $1: 0.8$ $(20 \mathrm{~mL}: 16 \mathrm{~mL}), \mathrm{N} 719=0.3 \mathrm{mg}, \mathrm{GNPs}=0.3 \mathrm{~mL})$ solar cells under illumination. Table 3 lists the characteristic parameters of solar cells with various substrates under 0.1 sun and 1 sun (AM 1.5) conditions, respectively. The parameters of solar cell with P3HT:PCBM+N719+GNP active layer on the PI substrate exhibited $J_{\mathrm{sc}}=3.89 \mathrm{~mA} / \mathrm{cm}^{2}, V_{\mathrm{oc}}=$ $0.45 \mathrm{~V}, \mathrm{FF}=0.266$, and a PCE of $4.65 \%$ under 0.1 sun 


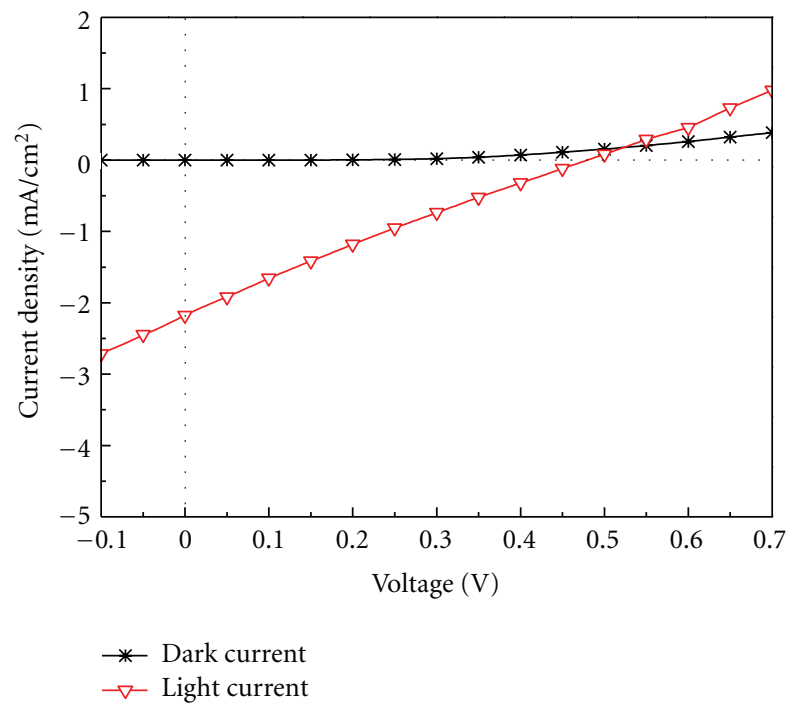

(a)

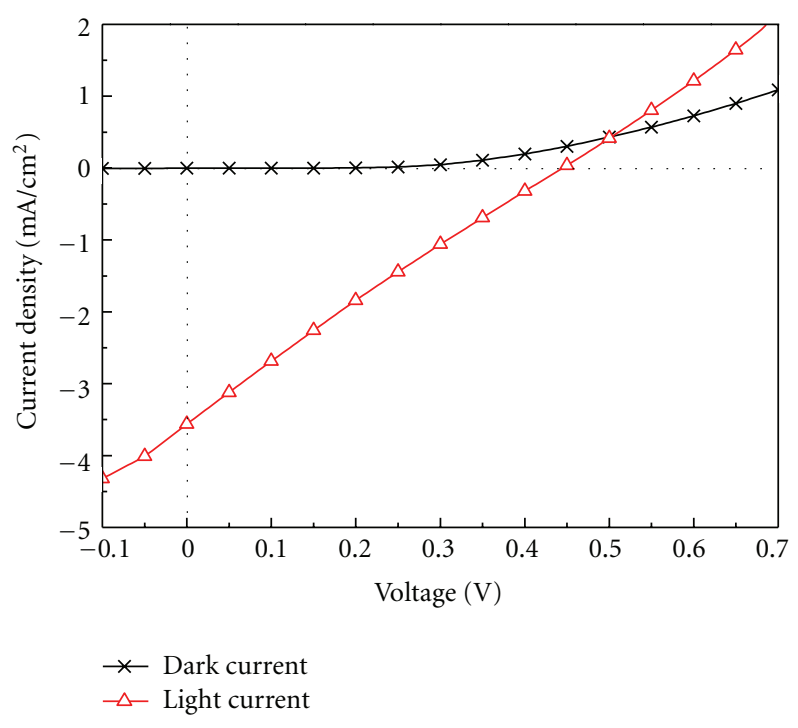

(b)

Figure 4: The $J-V$ characteristics of the solar cells with P3HT:PCBM+N719 active layer on (a) the PET substrate and (b) the PI substrate.

TABLE 2: The parameters of solar cells with P3HT:PCBM+N719 active layer.

\begin{tabular}{lcccc}
\hline Substrate & $V_{\text {oc }}(\mathrm{V})$ & $J_{\text {sc }}\left(\mathrm{mA} / \mathrm{cm}^{2}\right)$ & FF & \\
\hline Glass & 0.45 & 3.96 & 0.245 & 4.36 \\
PI & 0.4 & 3.56 & 0.258 & 3.68 \\
PET & 0.45 & 2.18 & 0.243 & 2.38 \\
\hline
\end{tabular}

TABLE 3: The parameters of solar cells with P3HT:PCBM+N719+GNP active layer.

\begin{tabular}{|c|c|c|c|c|c|}
\hline Condition & Substrate & $V_{\text {oc }}(\mathrm{V})$ & $J_{\mathrm{sc}}\left(\mathrm{mA} / \mathrm{cm}^{2}\right)$ & FF & $\eta(\%)$ \\
\hline \multirow{3}{*}{0.1 sun } & Glass & 0.45 & 4.06 & 0.261 & 4.76 \\
\hline & PI & 0.45 & 3.89 & 0.266 & 4.65 \\
\hline & PET & 0.45 & 2.87 & 0.248 & 3.21 \\
\hline \multirow{3}{*}{1 sun } & Glass & 0.50 & 13.48 & 0.211 & 1.42 \\
\hline & PI & 0.45 & 9.67 & 0.232 & 1.01 \\
\hline & PET & 0.45 & 9.31 & 0.232 & 0.97 \\
\hline
\end{tabular}

condition, respectively. The PCE was improved by approximately $42.2 \%$ over that of the control sample (without N719 and GNPs). Introducing N719 and GNPs may account for this improvement. When photo-generated electrons are injected into GNPs and the Fermi level $\left(E_{F}\right)$ is raised as close to the lowest unoccupied molecular orbital (LUMO) of P3HT as possible, a quick shuttling of electrons occurs from Au to P3HT. Therefore, GNPs promote the generation of charge carriers and increase both the photocurrent and the efficiency of conversion of solar energy in solar cells $[33,34]$. Meanwhile, the incorporation of N719 can assist transportation of the photo-generated electrons and holes. The energy level diagram and mechanism of photocurrent generation in the solar cells with P3HT:PCBM+N719+GNPs active layer is summarized in Figure 6. Finally, the efficiency improvement of solar cells with various active layers under condition of 0.1 sun are listed in Table 4 for easy reading and understanding.

\section{Conclusions}

This work demonstrated the feasibility of fabricating a flexible organic solar cell with a ITO/PEDOT:PSS/P3HT:PCBM + ruthenium complex sensitizer and Au nanoparticles structure on a flexible substrate. The process and thickness of PEDOT:PSS hole transport layer and P3HT:PCBM active layer were optimized. For the ITO/PEDOT:PSS/P3HT:PCBM + ruthenium complex sensitizer and $\mathrm{Au}$ nanoparticles structure on a flexible polyimide (PI) substrate under 0.1 and 1 sun conditions, the measured short-circuit current density $\left(J_{\mathrm{sc}}\right)$, open-circuit voltage $\left(V_{\mathrm{oc}}\right)$, fill factor $(\mathrm{FF})$, and efficiency $(\eta)$ are 3.89 and $9.67 \mathrm{~mA} / \mathrm{cm}^{2}, 0.45$ and 
TABLE 4: The efficiency improvement of solar cells with various active layers under condition of 0.1 sun.

\begin{tabular}{|c|c|c|c|c|c|}
\hline \multirow{2}{*}{ Substrate } & \multirow{2}{*}{$\begin{array}{c}\text { P3HT:PCBM } \\
\eta(\%)\end{array}$} & \multicolumn{2}{|c|}{ P3HT:PCBM+N719 } & \multicolumn{2}{|c|}{ P3HT:PCBM+N719+GNP } \\
\hline & & $\eta(\%)$ & Improvement $(\%)$ & $\eta(\%)$ & Improvement (\%) \\
\hline Glass & 4.1 & 4.36 & 6.34 & 4.76 & 16.1 \\
\hline PI & 3.27 & 3.68 & 12.54 & 4.65 & 42.2 \\
\hline PET & 2.24 & 2.38 & 6.25 & 3.21 & 43.3 \\
\hline
\end{tabular}

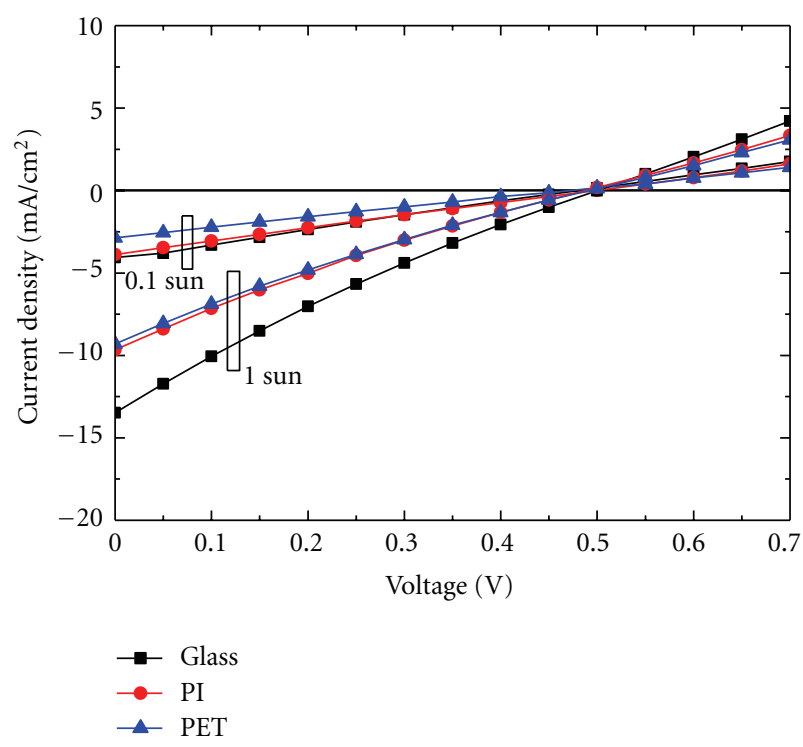

Figure 5: The $J-V$ characteristics of the solar cells with P3HT:PCBM+N719+GNPs active layer on various substrates.

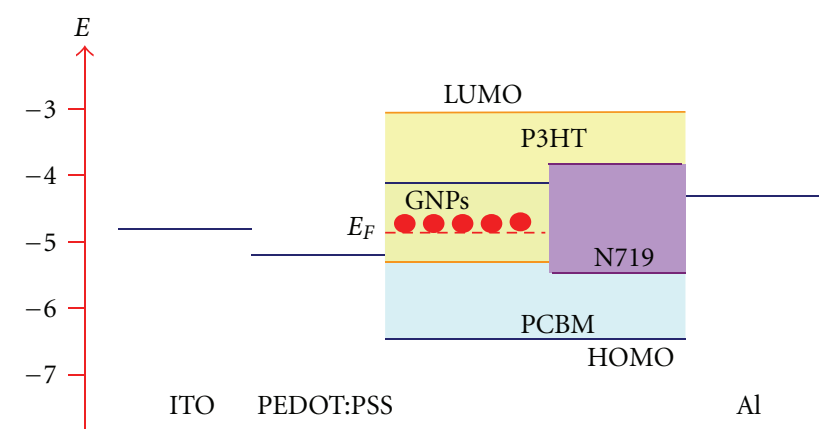

Figure 6: Energy level diagram and mechanism of photocurrent generation in the solar cells with P3HT:PCBM+N719+GNPs active layer.

$0.45 \mathrm{~V}, 0.266$ and 0.232 , and 4.65 and $1.01 \%$, respectively. Comprising the reported articles, the improved PCE of P3HT:PCBM-based FOSCs may be attributed to introduction of a ruthenium complex sensitizer and Au nanoparticles into the P3HT:PCBM active layer, subsequently increasing the photogenerated carrier injection.

\section{Acknowledgment}

Financial support of this work was provided by the National Science Council of the Republic of China under Contract no. NSC 100-2221-E-027-057.

\section{References}

[1] Y. S. Hsiao, C. P. Chen, C. H. Chao, and W. T. Whang, "Allsolution-processed inverted polymer solar cells on granular surface-nickelized polyimide," Organic Electronics, vol. 10, no. 4, pp. 551-561, 2009.

[2] I. Sasajima, S. Uesaka, T. Kuwabara, T. Yamaguchi, and K. Takahashi, "Flexible inverted polymer solar cells containing an amorphous titanium oxide electron collection electrode," Organic Electronics, vol. 12, no. 1, pp. 113-118, 2011.

[3] F. Wang, Z. Chen, L. Xiao, B. Qu, and Q. Gong, "Papery solar cells based on dielectric/metal hybrid transparent cathode," Solar Energy Materials and Solar Cells, vol. 94, no. 7, pp. 12701274, 2010.

[4] A. Bedeloglu, A. Demir, Y. Bozkurt, and N. S. Sariciftci, "A flexible textile structure based on polymeric photovoltaics using transparent cathode," Synthetic Metals, vol. 159, no. 1920, pp. 2043-2048, 2009.

[5] Y. T. Cheng, J. J. Ho, C. K. Wang et al., "Improvement of organic solar cells by flexible substrate and ITO surface treatments," Applied Surface Science, vol. 256, no. 24, pp. 76067611, 2010.

[6] P. Kopola, T. Aernouts, R. Sliz et al., "Gravure printed flexible organic photovoltaic modules," Solar Energy Materials and Solar Cells, vol. 95, no. 5, pp. 1344-1347, 2011.

[7] M. M. Voigt, R. C. I. MacKenzie, C. P. Yau et al., "Gravure printing for three subsequent solar cell layers of inverted structures on flexible substrates," Solar Energy Materials and Solar Cells, vol. 95, no. 2, pp. 731-734, 2011.

[8] M. Manceau, D. Angmo, M. Jørgensen, and F. C. Krebs, "ITOfree flexible polymer solar cells: from small model devices to roll-to-roll processed large modules," Organic Electronics, vol. 12, no. 4, pp. 566-574, 2011.

[9] F. C. Krebs, "Polymer solar cell modules prepared using rollto-roll methods: knife-over-edge coating, slot-die coating and screen printing," Solar Energy Materials and Solar Cells, vol. 93, no. 4, pp. 465-475, 2009.

[10] N. Espinosa, R. García-Valverde, A. Urbina, and F. C. Krebs, "A life cycle analysis of polymer solar cell modules prepared using roll-to-roll methods under ambient conditions," Solar Energy Materials and Solar Cells, vol. 95, no. 5, pp. 1293-1302, 2011.

[11] B. Zimmermann, H. F. Schleiermacher, M. Niggemann, and U. Würfel, "ITO-free flexible inverted organic solar cell modules with high fill factor prepared by slot die coating," Solar Energy Materials and Solar Cells, vol. 95, no. 7, pp. 1587-1589, 2011. 
[12] F. C. Krebs, "All solution roll-to-roll processed polymer solar cells free from indium-tin-oxide and vacuum coating steps," Organic Electronics, vol. 10, no. 5, pp. 761-768, 2009.

[13] T. T. T. Luong, Z. Chen, and H. Zhu, "Flexible solar cells based on copper phthalocyanine and buckminsterfullerene," Solar Energy Materials and Solar Cells, vol. 94, no. 6, pp. 1059-1063, 2010.

[14] C. J. Brabec, N. S. Sariciftci, and J. C. Hummelen, "Plastic solar cells," Advanced Functional Materials, vol. 11, no. 1, pp. 15-26, 2001.

[15] M. Al-Ibrahim, H. K. Roth, U. Zhokhavets, G. Gobsch, and S. Sensfuss, "Flexible large area polymer solar cells based on poly(3-hexylthiophene)/ fullerene," Solar Energy Materials and Solar Cells, vol. 85, no. 1, pp. 13-20, 2005.

[16] J. P. Liu, K. L. Choy, and X. H. Hou, "Charge transport in flexible solar cells based on conjugated polymer and $\mathrm{ZnO}$ nanoparticulate thin films," Journal of Materials Chemistry, vol. 21, no. 6, pp. 1966-1969, 2011.

[17] N. Sun, G. Fang, P. Qin et al., "Efficient flexible organic solar cells with room temperature sputtered and highly conductive $\mathrm{NiO}$ as hole-transporting layer," Journal of Physics D, vol. 43, no. 44, Article ID 445101, 2010.

[18] Y. Liang, Z. Xu, J. Xia et al., "For the bright future-bulk heterojunction polymer solar cells with power conversion efficiency of 7.4\%," Advanced Materials, vol. 22, no. 20, pp. E135-E138, 2010.

[19] K. Akamatsu, S. Ikeda, and H. Nawafune, "Site-selective direct silver metallization on surface-modified polyimide layers," Langmuir, vol. 19, no. 24, pp. 10366-10371, 2003.

[20] H. K. Kim, J. A. Jeong, K. H. Choi, S. W. Jeong, and J. W. Kang, "Characteristics of flexible ito electrodes grown by continuous facing target roll-to-roll sputtering for flexible organic solar cells," Electrochemical and Solid-State Letters, vol. 12, no. 5, pp. H169-H172, 2009.

[21] G. Yu, J. Gao, J. C. Hummelen, F. Wudl, and A. J. Heeger, "Polymer photovoltaic cells: enhanced efficiencies via a network of internal donor-acceptor heterojunctions," Science, vol. 270, no. 5243, pp. 1789-1791, 1995.

[22] M. A. López, J. C. Sánchez, and M. Estrada, "Characterization of PEDOT:PSS dilutions for inkjet printing applied to OLED fabrication," in Proceedings of the 7th International Caribbean Conference on Devices, Circuits and Systems (ICCDCS'08), pp. 1-4, Cancun, Mexico, April 2008.

[23] S. K. Hau, H. L. Yip, J. Zou, and A. K. Y. Jen, "Indium tin oxide-free semi-transparent inverted polymer solar cells using conducting polymer as both bottom and top electrodes," Organic Electronics, vol. 10, no. 7, pp. 1401-1407, 2009.

[24] E. Vitoratos, S. Sakkopoulos, E. Dalas et al., "Thermal degradation mechanisms of PEDOT:PSS," Organic Electronics, vol. 10, no. 1, pp. 61-66, 2009.

[25] B. Friedel, P. E. Keivanidis, T. J. K. Brenner et al., "Effects of layer thickness and annealing of PEDOT:PSS layers in organic photodetectors," Macromolecules, vol. 42, no. 17, pp. 67416747, 2009.

[26] S. M. Sze, Physics of Semiconductor Devices, John Wiley \& Sons, New York, NY, USA, 2nd edition, 1981.

[27] K. Nishioka, T. Takamoto, T. Agui, M. Kaneiwa, Y. Uraoka, and T. Fuyuki, "Evaluation of InGaP/InGaAs/Ge triple-junction solar cell and optimization of solar cell's structure focusing on series resistance for high-efficiency concentrator photovoltaic systems," Solar Energy Materials and Solar Cells, vol. 90, no. 9, pp. 1308-1321, 2006.

[28] W. H. Lee, S. Y. Chuang, H. L. Chen, W. F. Su, and C. H. Lin, "Exploiting optical properties of P3HT:PCBM films for organic solar cells with semitransparent anode," Thin Solid Films, vol. 518, no. 24, pp. 7450-7454, 2010.

[29] T. Horiuchi, H. Miura, K. Sumioka, and S. Uchida, "High efficiency of dye-sensitized solar cells based on metal-free indoline dyes," Journal of the American Chemical Society, vol. 126, no. 39, pp. 12218-12219, 2004.

[30] S. Q. Fan, C. Kim, B. Fang et al., "Improved efficiency of over $10 \%$ in dye-sensitized solar cells with a ruthenium complex and an organic dye heterogeneously positioning on a single $\mathrm{TiO}_{2}$ electrode," Journal of Physical Chemistry C, vol. 115, no. 15, pp. 7747-7754, 2011.

[31] M. K. Nazeeruddin, R. Humphry-Baker, P. Liska, and M. Grätzel, "Investigation of sensitizer adsorption and the influence of protons on current and voltage of a dye-sensitized nanocrystalline $\mathrm{TiO}_{2}$ solar cell," Journal of Physical Chemistry B, vol. 107, no. 34, pp. 8981-8987, 2003.

[32] S. W. Tong, C. F. Zhang, C. Y. Jiang et al., "Improvement in the hole collection of polymer solar cells by utilizing gold nanoparticle buffer layer," Chemical Physics Letters, vol. 453, no. 1-3, pp. 73-76, 2008.

[33] C. Hägglund, M. Zäch, and B. Kasemo, "Enhanced charge carrier generation in dye sensitized solar cells by nanoparticle plasmons," Applied Physics Letters, vol. 92, no. 1, Article ID 013113, 3 pages, 2008.

[34] S. Barazzouk and S. Hotchandani, "Enhanced charge separation in chlorophyll a solar cell by gold nanoparticles," Journal of Applied Physics, vol. 96, no. 12, pp. 7744-7746, 2004. 

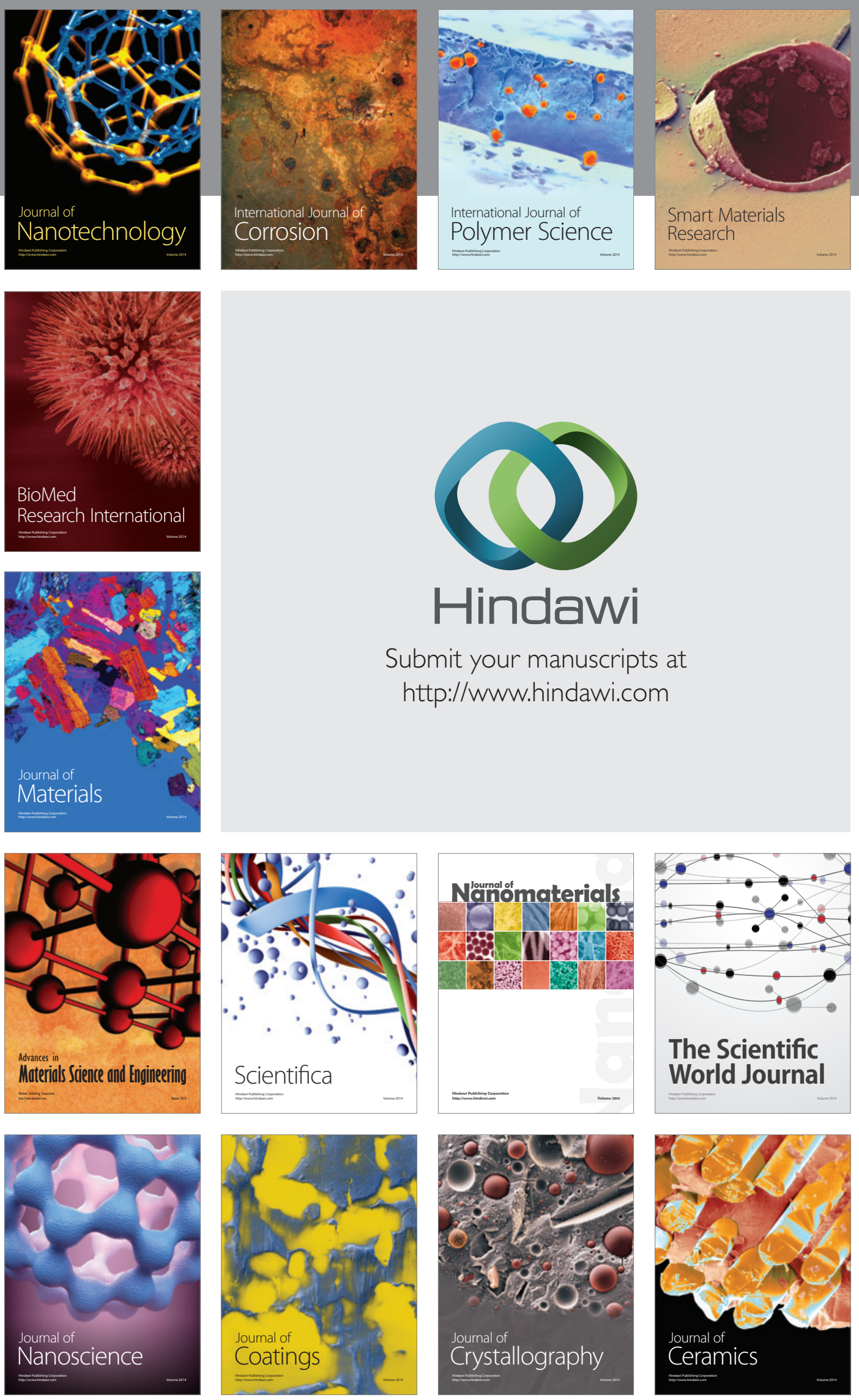

The Scientific World Journal

Submit your manuscripts at

http://www.hindawi.com

\section{World Journal}

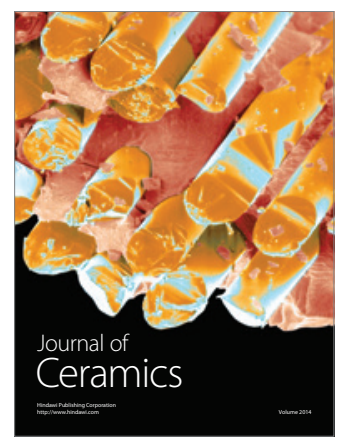

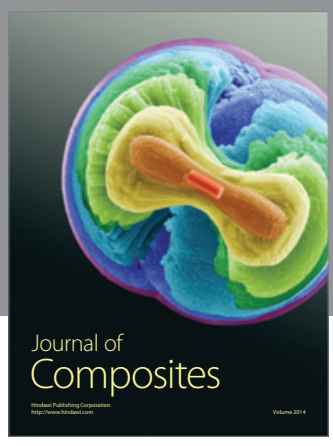
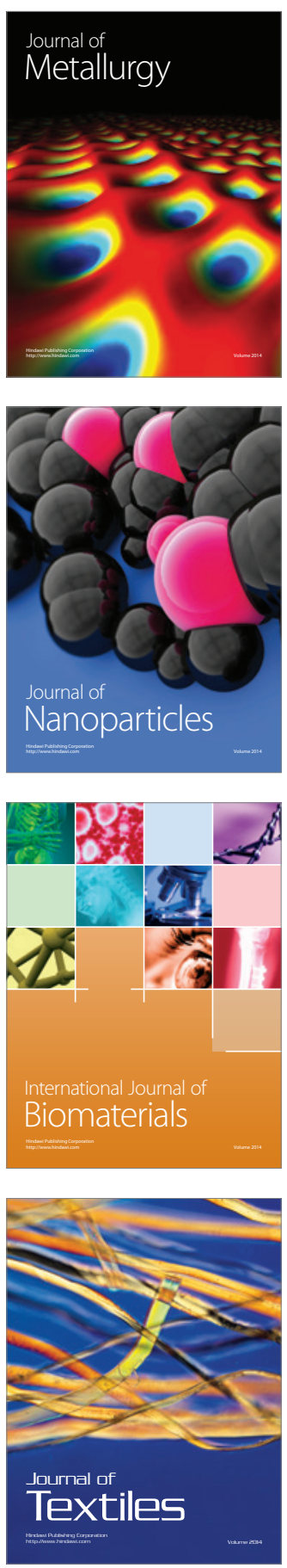